\title{
PRINSIP PERHUBUNGAN AWAM MENURUT PERSPEKTIF ISLAM: PENELITIAN KONSEPTUAL
}

\section{Principles of Public Relations Based on the Islamic Perspective: Conceptual Research}

\author{
Ahmad Al-Munzir Ridzuan ${ }^{1}$ \\ Nor 'Azzah Kamri' \\ Zulkifli Mohd Yusoff ${ }^{3}$
}

\begin{abstract}
Public relations are one of the essential elements for most of the organisations today. It is a center of focus in the organisations for channeling and disseminating the information both internally and internationally. Usually, public relations unit is the entity that responsible and directly involved in the public relations process. However, in the absence of a dedicated public relations unit, other people or units play a role in carrying out public relations responsibilities. In fact, most of the organisations use public relations to handle current issues or difficulties. Besides,
\end{abstract}

1 PhD Candidate, Department of Shariah and Management, Academy of Islamic Studies, University of Malaya, 50603 Kuala Lumpur, Malaysia, munzir5059@ gmail.com

2 Senior Lecturer, Department of Shariah and Management, Academy of Islamic Studies, University of Malaya, 50603 Kuala Lumpur, Malaysia, azzah@um.edu. my

3 Professor, Department of Al-Quran and Al-Hadith, Academy of Islamic Studies, University of Malaya, 50603 Kuala Lumpur, Malaysia, zulkifly@um.edu.my 


\begin{abstract}
it is used as one of the channels to publicize the achievements and successes achieved by the organisations. While conducting public relations, it might cause several issues such as non-transparency, interruption and inconsistencies. These should be avoided because they are not only destroying the social norms but also religious norms. Thus, this article will explain the fundamentals of Islamic public relations. Data are gathered through library study, as well as research on the Qur'an, Sunnah, and history. Next, it will be analysed using content analysis. Based on the findings, there are five elements of Islamic public relations: (1) create understanding, (2) protect the truth, (3) honor the promises, (4) use acceptable language and (5) take appropriate approach. The outcomes of this research will contribute to the development of knowledge in the field of public relations in general and Islamic public relations in particular.
\end{abstract}

Keywords: Principles, Public Relations, Islam

\title{
PENDAHULUAN
}

Perhubungan awam merupakan elemen yang sangat penting bagi kebanyakan organisasi kontemporari. Secara amnya, kebanyakan organisasi meletakkan tanggungjawab dan beban tugas ini secara khusus kepada unit perhubungan awam dalam organisasi mereka. Walau bagaimanapun, terdapat juga organisasi yang tidak mempunyai unit perhubungan awam secara khusus namun meletakkan tanggungjawab dan beban tugas tersebut kepada individu atau unit tertentu dalam hierarki pengurusan organisasi mereka.

Hal ini disebabkan peranannya yang bertindak sebagai sebagai titik fokus (focal point) organisasi dalam proses penyaluran dan hebahan maklumat sama ada di peringkat dalaman mahupun luaran organisasi berlandaskan kepentingan dan faedah bersama. Tuntasnya, pengurusan dan pengaplikasian perhubungan awam yang baik mampu memberi impak yang sangat signifikan terhadap kelestarian imej dan reputasi serta kelangsungan organisasi. Walau bagaimanapun, evolusi dan transisi masa telah menyebabkan proses perhubungan awam mengalami suatu anjakan paradigma yang semakin sulit. ${ }^{4}$

$4 \quad$ Periasamy Muthan, 'Peranan dan Amalan Perhubungan Awam di Malaysia: Satu Kajian Kes Terhadap Pegawai Perhubungan Awam Kerajaan' (Disertasi Sarjana, Pusat Pengajian Komunikasi, Universiti Sains Malaysia, Pulau Pinang, 2007), 177. 
Realitinya, setiap organisasi tidak akan dapat lari dari dibelenggu isu atau masalah. Justeru, perhubungan awam merupakan salah satu senjata yang ampuh bagi memastikan isu dan masalah yang membelenggu tersebut tidak memberi impak yang negatif terhadap organisasi. ${ }^{5}$ Dalam masa yang sama, perhubungan awam turut berfungsi dalam menguar-uarkan kejayaan dan pencapaian yang diperoleh organisasi bagi menaikkan lagi imej dan reputasinya.

Justeru, dalam memenuhi tuntutan fungsinya sebagai benteng dan pemangkin imej dan reputasi serta kelangsungan organisasi, ia wajar dilakukan dengan penuh dedikasi. Walau bagaimanapun, penelitian terhadap kajian lepas mendapati terdapat pelbagai kelompongan wujud sama ada di fasa perancangan, perlaksanaan dan penilaian. Hal ini disebabkan oleh ketiadaan proses perhubungan awam yang strategik. Kesannya ialah proses perhubungan awam yang dijalankan memberi impak yang negatif terhadap organisasi disebabkan proses perhubungan awam yang salah. Contohnya ialah dapatan kajian yang dilakukan oleh Saidatul Nizah Mat Tazin dan Kiranjit Kaur ${ }^{6}$ yang mendapati bahawa Tenaga Nasional Berhad (TNB) tidak mempunyai asas perancangan perhubungan awam yang strategik. Kesannya ialah proses perhubungan yang berlaku memenuhi keperluan yang salah dan ditujukan kepada orang yang salah.

Selain itu juga, penelitian mendapati bahawa terdapat organisasi yang menggunapakai perhubungan awam dengan cara yang tidak wajar. Kebanyakan tindakan tidak wajar yang dilakukan oleh organisasi sebenarnya bukanlah secara kebetulan bahkan ia bermula daripada fasa perancangan perhubungan awam. ${ }^{7}$ Antara contoh tindakan yang tidak wajar yang dilakukan dalam proses perhubungan awam ialah ketidaktelusan, sela-menyela dan tidak konsisten dalam proses penyampaian atau hebahan maklumat.

Hal ini sebagaimana berlaku kepada masyarakat yang kecewa dengan keputusan kerajaan berkaitan tatacara pengendalian piawaian (standard operating procedure) perintah kawalan pergerakan yang sering berubah-

5 Nik Roskiman Abdul Samad, 'Peranan Media dalam Melestarikan Masyarakat Kasih Sayang', Prosiding Wacana Keputeraan Sultan Muhammad V (Jeli: Universiti Malaysia Kelantan, 2015), 181-192.

6 Saidathul Nizah Mat Tazin \& Kiranjit Kaur, 'Strategic Crisis Communication and Stakeholder Reactions in a Malaysian Government-Linked Company', Media Asia, vol. 41/1 (2014): 25-30.

7 James E. Grunig \& Fred C. Repper, 'Strategic Management, Publics and Issues', dalam Excellence in Public Relations and Communication Management, ed. James E. Grunig (New Jersey: Lawrence Erlbaum, 1992), 109-114. 
ubah. ${ }^{8}$ Walau bagaimanapun, pihak kerajaan mempertahankan tindakan ini disebabkan perkembangan penularan pandemik yang sedang melanda negara. ${ }^{9}$ Dari perspektif lain, pengkaji melihat bahawa situasi ini berkemungkinan disebabkan oleh keperluan kerajaan untuk menyeimbangkan kawalan kesihatan awam dengan imej dan reputasinya disamping hubungan yang baik dengan masyarakat. Hal ini dapat dilihat melalui perubahan yang berlaku pada tatacara pengendalian piawaian Tahun Baru Cina. ${ }^{10}$ Justeru, sesuatu keputusan yang dibuat dan tindakan yang dipilih berkemungkinan atas dapatan penilaian risiko mereka bagi mengelakkan impak yang negatif bukan hanya terhadap organisasi semata-mata bahkan terhadap masyarakat juga. ${ }^{11}$

Literasi maklumat dalam kalangan masyarakat juga berkemungkinan menjadi faktor penyebab organisasi perlu melakukan tindakan sedemian rupa bagi memastikan imej dan reputasinya tidak tergugat seterusnya memastikan kelangsungan organisasinya. Hakikatnya, tindakan tersebut boleh diibaratkan "memagar diri bagai aur" walhal sebagai organisasi yang bertanggungjawab, tindakan tersebut tidak wajar dilakukan kerana bukan sahaja menggadaikan norma bermasyarakat, bahkan norma beragama.

Dalam Islam, norma dan tingkahlaku yang baik bukan sahaja bagi memenuhi hak bermasyarakat semata-mata, bahkan turut membantu organisasi mencapai matlamat yang telah dirangka. Jika diperincikan dalam konteks perhubungan awam, tuntutan ini adalah selaras dengan firman Allah SWT:

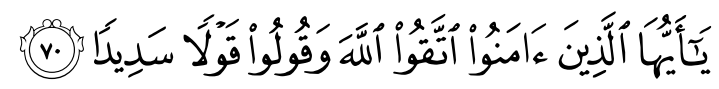

"Wahai orang-orang yang beriman, bertakwalah kamu kepada Allah dan katakanlah perkataan yang benar."

(Surah al-Ahzāb, 33:70)

8 'Warganet Kecewa Keputusan "Flip Flop" Kerajaan Berkait PKP', Freemalaysiatoday (Petaling Jaya, 2021) https:/www.freemalaysiatoday.com/ category/bahasa/tempatan/2021/05/11/warganet-kecewa-keputusan-flip-flopkerajaan-berkait-pkp/, dicapai pada 18 Mei 2021.

9 Azneal Ishak, 'Ismail Sabri Defends Flip-Flop SOPs Following Public Outrage', Malaysiakini (Kuala Lumpur, 2021) https://www.malaysiakini.com/news/574302, dicapai pada 18 Mei 2021.

10 Ekhwan Haque Fazlul Haque, 'SOP Tahun Baru Cina Hasil Persetujuan Dengan 21 Pertubuhan Agama Berkaitan', MyMetro (Kuala Lumpur, 2021) <https:// www.hmetro.com.my/mutakhir/2021/02/671619/sop-tahun-baru-cina-hasilpersetujuan-dengan-21-pertubuhan-agama-berkaitan>, dicapai pada 18 Mei 2021.

11 James E. Grunig dan Larissa A. Grunig, Guidelines for Formative and Evaluative Research in Public Affairs (Maryland: University of Maryland, 2001). 8. 
Begitu juga Nabi Muhammad SAW yang turut menuntut agar umatnya sentiasa melaksanakan perkara tersebut dalam setiap tindakan mereka sebagaimana sabda Nabi SAW:

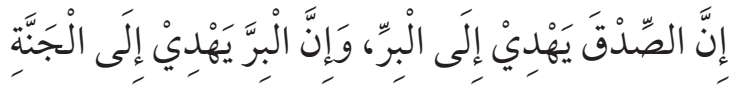

$$
\begin{aligned}
& \text { "Sesungguhnya kejujuran membawa kepada kebaikan dan } \\
& \text { kebaikan membawa seseorang ke syurga." } 12
\end{aligned}
$$

Dalam konteks kajian ini, laras perbahasan yang dilakukan adalah memfokuskan kepada prinsip yang mendasari perlaksanaan perhubungan awam dalam sesebuah organisasi berlandaskan kerangka Islam melalui penelitian terhadap beberapa sumber. Dalam konteks pekerjaan, pemahaman tentang prinsip adalah berkaitan dengan dasar atau peraturan yang digunakan dalam menjalankan kerja rutin. ${ }^{13}$ Justeru, kajian ini penting bagi meneliti dan merungkai pandangan Islam tentang asas kepada tadbir urus perhubungan awam. Firman Allah SWT:

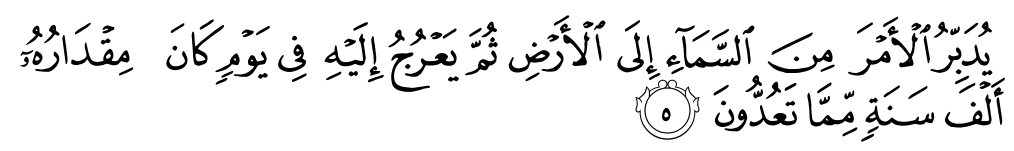

"Dia yang mengatur urusan dari langit ke bumi, kemudian (urusan) itu naik kepadanya dalam satu hari yang kadarnya adalah seribu tahun menurut penghitunganmu”.

(Surah al-Sajdah, 32: 5)

Berdasarkan ayat di atas dapatlah diketahui bahawa Allah SWT adalah pengatur dan pencipta alam ini. Keteraturan alam ini menjadi bukti kekuasaan dan kebesaran Allah SWT dalam mengatur dan mengelola alam ini. Justeru, sebagai khalifah Allah SWT di atas muka bumi ini, maka manusia harus mengatur dan mengelola bumi dengan sebaiknya sebagaimana yang Allah SWT telah tetapkan.

Jika ditinjau, perbahasan secara ilmiah berkaitan perhubungan awam Islam ini sebenarnya masih baru walaupun dari aspek praktisnya telah lama dilaksanakan. Hal ini dapat diteliti melalui jumlah kajian lepas yang berhubungkait dengannya. Justeru, ruang penelitian dan perbahasan terhadapnya adalah masih terbuka luas. Berdasarkan fakta ini, makalah ini akan membincangkan tentang prinsip perhubungan awam menurut perspektif

12 Al-Bukhārī, Șah̄ịh al-Bukhārī (Bayrūt: Dār Ibn Kathīr, 2002), "Kitāb al-Adāb, Bāb wamā yanhā 'an al-kazib," no. hadis 6094.

13 Stephen P. Robbins, Organization Behavior: Concepts, Controvercies and Application, $8^{\text {th }}$ ed. (New Jersey: Prentice Hall, 1998), 634. 
Islam dengan penelitian terhadap ayat al-Quran, Hadis, sirah dan kajian lepas. Dapatan daripada penelitian ini akan membawa kepada perkembangan pengkajian dalam bidang perhubungan awam amnya dan perhubungan awam Islam khususnya.

\section{DEFINISI DAN KONSEP PERHUBUNGAN AWAM MENURUT PERSPEKTIF ISLAM}

Secara amnya, terdapat pelbagai takrifan perhubungan awam yang dikemukan oleh para sarjana perhubungan awam. Hal ini disebabkan pendefinisian perhubungan awam adalah berdasarkan pertimbangan suasana dan keperluan organisasi atau setempat. Disamping itu juga, faktor fungsi dan kedudukan perhubungan awam dalam sesebuah organisasi turut mempengaruhi pendefinisiannya. ${ }^{14}$ Walau bagaimanapun, secara asasnya, terdapat dua elemen penting yang terkandung di dalamnya iaitu "perhubungan" dan "awam". Dalam konteks ini, perhubungan merujuk kepada komunikasi atau perantaraan, ${ }^{15}$ manakala awam pula merujuk kepada orang awam, khalayak pilihan atau khalayak sasaran. ${ }^{16}$

Menurut Rex F. Harlow ${ }^{17}$ dan Dennis L. Wilcox, Glen T. Cameron dan Bryan H. Reber $^{18}$, perhubungan awam merupakan salah satu fungsi pengurusan dalam usaha untuk mengekalkan persefahaman sama ada dalam aspek komunikasi, pemahaman dan kerjasama antara organisasi dengan masyarakat melibatkan pengurusan isu. Selain itu juga, perhubungan awam turut berfungsi dalam membantu organisasi untuk memberi maklum balas terhadap masyarakat, mengingatkan pengurusan organisasi tentang tanggungjawabnya terhadap masyarakat dan memaklumkan perkembangan terkini berkaitan persekitaran organisasi serta bertindak sebagai sistem amaran awal untuk sebarang perubahan di luar jangka.

14 Mokhtarrudin Ahmad, 'Amalan Perhubungan Awam: Kajian Terhadap Kecemerlangan dan Amalan Perhubungan Awam di Organisasi Tersenarai di Bursa Malaysia' (Tesis Doktor Falsafah, Pusat Pengajian Komunikasi, Universiti Sains Malaysia, Pulau Pinang, 2011). 23.

15 Kamus Dewan, $4^{\text {th }}$ ed. (Kuala Lumpur: Dewan Bahasa dan Pustaka, 2005), 1443.

16 Kamus Dewan, $4^{\text {th }}$ ed. 244.

17 Rex. F. Harlow, 'Public relations definitions throught the years', Public Relations Review, vol. 3/1 (1977): 49-63.

18 Dennis L. Wilcox, Glen T. Cameron dan Bryan H. Reber, Public Relations: Strategies and Tactics, $11^{\text {th }}$ ed. (New York: Pearson Education Inc, 2015), 33. 
Kevin Moloney ${ }^{19}$ pula menggambarkan bahawa hubungan yang ingin dibangunkan oleh organisasi dengan masyarakat melalui aktiviti perhubungan awam sebagai satu bentuk usaha penonjolan diri oleh organisasi untuk meraih perhatian dan memperoleh keuntungan daripada khalayaknya. Dalam hal ini, perhubungan awam bertindak sebagai agen penengah antara kedua-duanya melalui pengekalan imej dan reputasi organisasi serta hubungan baik dengan masyarakat secara berterusan.

Dalam menyeimbangkan kehendak organisasi dan masyarakat serta proses perhubungan awam yang dilaksanakan selaras dengan keperluan masyarakat, proses penyelidikan wajar dilakukan. Hal ini sebagaimana yang dinyatakan oleh Scott M. Cutlip dan Glen M. Broom. ${ }^{20}$ Menurut mereka, perhubungan awam harus bermula dengan penilaian tingkahlaku masyarakat, mengenalpasti polisi dan peraturan yang sesuai dengan keperluan masyarakat, merancang dan menjalankan aktiviti bagi memastikan masyarakat memahami dan menerima tingkahlaku organisasi.

Tuntasnya, pendefinisian yang dikemukakan menurut perspektif konvensional ini boleh dirumuskan kepada empat persepektif. ${ }^{21}$ Pertama, perhubungan awam menjalankan fungsi pengurusan. Kedua, perhubungan awam menjalankan fungsi perancangan. Ketiga, perhubungan awam menjalankan fungsi pelaksana. Keempat, perhubungan awam menjalankan fungsi penilaian.

Pendefinisan perhubungan awam menurut perspektif Islam boleh dirujuk melalui pendefinisian yang telah dikemukakan oleh beberapa orang sarjana. Menurut Mansur Uthman, ${ }^{22}$ perhubungan awam Islam merupakan satu proses pembinaan hubungan antara organisasi dengan masyarakat bagi membentuk suasana yang harmoni.

19 Kevin Moloney, Rethinking Public Relations: PR Propaganda and Democracy, $2^{\text {nd }}$ ed. (Oxfordshire: Routledge, 2006), 141.

20 Scott M. Cutlip dan Glen M. Broom, Effective Public Relations (New Jersey: Prentice Hall, 2009), 46.

21 Syed Arabi Idid Syed Abdullah dan Mohd Safar Hasim, Perhubungan Awam di Malaysia: Satu Kajian Tentang Pengamal di Malaysia (Bangi: Universiti Kebangsaan Malaysia, 1995), 10.

22 Manșūr 'Uțhmān Muhạmmad Zīn, al-Manẓūr al-Islāmī li al-'Alāqāt al- 'Āmah (Omdurman, Sūdān: Omdurman Islamic University, 2008), 1. 
Mohammed Kirat ${ }^{23}$ pula telah mendefinisikan perhubungan awam Islam sebagai satu kaedah dalam mewujudkan persekitaran yang sihat berlandaskan dalil-dalil yang terkandung di dalam al-Quran dan al-Sunnah. Hal ini selari dengan pendefinisian yang dikemukakan oleh Md Shahidul dan Jamilah. ${ }^{24}$ Menurut mereka, perhubungan awam Islam merupakan satu proses bagi membina suasana yang harmoni antara organisasi dan masyarakat berlandaskan kerangka dan ideologi Islam.

Berdasarkan pendefinisian dari kedua-dua perspektif ini, maka pengkaji dapat merumus dan mengemukakan bahawa perhubungan awam Islam merupakan satu fungsi pengurusan yang berstrategi, perlaksanaan yang sistematik dan penilaian yang menyeluruh bagi mencapai matlamat yang telah ditetapkan melalui pembentukan jalinan muhibah antara organisasi dengan masyarakat berlandaskan prinsip-prinsip yang terkandung di dalam al-Quran dan al-Sunnah serta tidak bertentangan dengan norma masyarakat.

\section{SEJARAH PEHUBUNGAN AWAM ISLAM}

Perhubungan awam merupakan salah satu cabang daripada ilmu komunikasi yang telah dipraktikkan sejak zaman-berzaman. Sebahagian sarjana menyatakan bahawa perhubungan awam merupakan satu ilmu yang muncul pada abad ke20. Selain itu, terdapat juga sarjana yang berpandangan bahawa perhubungan awam telah wujud seawal 1800 tahun sebelum masihi sebagaimana yang terkandung dan diamalkan dalam peradaban kuno seperti di Babylon yang merupakan salah satu daripada negara dalam tamadun Mesopotamia. ${ }^{25}$

Walau bagaimanapun, pada zaman tersebut, ia tidak dikenali sebagai perhubungan awam namun praktis perhubungan awam itu berlaku dalam kehidupan mereka seharian seperti membujuk, menyebarkan informasi dan mengintegrasikan masyarakat. ${ }^{26}$ Rentetan daripada praktis tersebut, ia telah

23 Mohamed Kirat, 'The Islamic Roots of Modern Public Relations and Corporate Social Responsibility', International Journal of Islamic Marketing and Branding, vol. 1/1 (2015): 97-112.

24 Md Shahidul Haque dan Jamilah Ahmad, 'The Role of Islamic Public Relations in Leadership', dalam International Conference on Islamic Leadership and Management (ICILM 2016) (Bandar Seri Begawan: Universiti Islam Sultan Sharif Ali, 2016), 252-264.

25 Tim P. Vos, 'Explaining the Origins of Public Relations: Logics of Historical Explanation', Journal of Public Relations Research, vol. 23/2 (2011): 119-140.

26 Sulvinajayanti, 'Praktik Public Relation dalam Pandangan Islam', KOMUNIDA: Media Komunikasi dan Dakwah, vol. 8/2 (2018): 134-154. 
mewujudkan suasana yang harmoni. Suasana yang harmoni ini terhasil daripada hubungan yang saling menguntungkan dalam kalangan masyarakat dalam menjalani kehidupan seharian.

Jika disoroti sejarah, terdapat pelbagai kisah yang memaparkan bahawa praktis perhubungan awam telah sekian lama bertapak di dunia. Antaranya ialah praktis perhubungan awam oleh Nabi Muhammad SAW dan Raja Najasyi. Dalam kisah ini, Nabi Muhammad SAW telah mengutuskan Ja'far bin Abu Talib sebagai ketua delegasi umat Islam dengan membawa perutusan Baginda SAW kepada Raja Najasyi yang merupakan pemerintah Habsyah ketika itu. Raja Najasyi telah menerima dan melayani delegasi tersebut dengan sangat baik. Baginda kemudiannya menghantar pulang kembali Ja'far bin Abu Talib beserta delegasi tersebut dengan menggunakan kapal. ${ }^{27}$

Peristiwa ini memaparkan suatu praktis perhubungan awam yang sangat baik dimainkan oleh kedua-dua belah pihak. Ini kerana, praktis perhubungan awam tidak hanya terhenti pada langkah awal atau pertemuan kali pertama semata-mata bahkan seharusnya ia disusuli dengan langkah atau pertemuan yang berlanjutan.

Hakikatnya, terdapat pelbagai lagi kisah dan peristiwa yang menonjolkan kehebatan Nabi Muhammad SAW dalam mempraktikkan perhubungan awam. Secara asasnya, terdapat empat sifat yang menjadikan Nabi Muhammad SAW sebagai model yang terbaik dalam pengaplikasian perhubungan awam. ${ }^{28}$ Pertama, sifat benar (siddiq) iaitu keselarasan antara kata-kata dengan tindakan. Kedua, sifat jujur (amanah) iaitu konsisten dalam melaksanakan tanggungjawab yang dipikul. Ketiga, sifat komunikatif (tabligh) iaitu keupayaan untuk menyampaikan maklumat atau berinteraksi dengan ringkas dan mudah difahami serta tidak mengungkapkan tutur kata yang boleh menyinggung perasaan masyarakat. Keempat, sifat bijaksana (fathanah) iaitu keupayaan akalnya untuk mencerna dan menjawab pertanyaan, berdebat dengan penentangnya dan lain-lain.

Impak daripada kehebatan Nabi Muhammad SAW dalam mengaplikasi perhubungan awam ialah ajaran Islam semakin mendapat perhatian dan tempat dihati masyarakat dunia sehingga kini. Potensi luar biasa ini juga turut diiktiraf oleh barat sehingga menempatkan nama Baginda SAW di tempat yang pertama

27 Mustafa As-Syibaie, Sirah Nabi Muhammad SAW Pengajaran dan Pedoman, terj. Bahagian Penterjemahan dan Suntingan Pustaka Salam Sdn. Bhd. (Rawang: Pustaka Salam, 2010), 28.

28 Sulvinajayanti, ‘Praktik Public Relation dalam Pandangan Islam', 134-154. 
dalam seratus individu paling berpengaruh dalam lipatan sejarah. ${ }^{29}$ Hal ini kerana, dalam tempoh satu abad, Islam telah tersebar ke seluruh pelosok dunia dan telah menghancurkan beberapa kerajaan besar serta melenyapkan beberapa agama tersohor yang diamalkan sebelumnya. ${ }^{30}$

Jika diteliti dari aspek sejarah awal perhubungan awam yang dijalankan di kesultanan Melayu, tanggungjawab dan beban tugas perhubungan awam banyak diletakkan kepada utusan atau wakil. ${ }^{31}$ Justeru, peranan utusan atau wakil tersebut dalam menjalankan fungsi perhubungan awam boleh diibaratkan seperti 'berat beban senggulung batu'. Ini kerana, kegagalannya dalam melaksanakan beban tugas tersebut bakal memberikan impak negatif terhadap institusi pemerintahan.

Dalam Bustan al-Salitin, telah disenaraikan 10 ciri-ciri yang perlu ada bagi seorang utusan atau wakil yang ingin dihantar pada zaman kesultanan Melayu. Pertama, hendaklah takut kepada Allah SWT dan teguh agamanya. Kedua, hendaklah berpengetahuan. Ketiga, elok rupa parasnya. Keempat, dipercayai. Kelima, fasih lidahnya dan baik suaranya. Keenam, bijaksana. Ketujuh, berani. Kelapan, baik kelakukannya dan akalnya. Kesembilan, pemurah dan bangsawan. Kesepuluh, tidak tamak. ${ }^{32}$

Selain itu, perhubungan awam di zaman kesultanan Melayu turut menggunapakai warkah. Menurut Adib Imran ${ }^{33}$, warkah merupakan salah satu landasan utama interaksi atau perhubungan awam pada zaman tersebut. Jika disoroti sejarah, Sultan Muzaffar Syah merupakan antara pemerintah yang terawal memulakan tradisi mengirim warkah sebagai salah satu kaedah perhubungan awam. ${ }^{34}$ Begitu juga sebagaimana yang dilakukan oleh Sultan

29 Michael H. Hart, The 100: A Ranking of the Most Influential Persons in History, $2^{\text {nd }}$ edn (New York: Hart Publishing Company, 1992), 3.

30 Lothrop Stoddard, The New World of Islam (London: Chapman and Hall Ltd, 1922), 21.

31 Rozita Che Rodi, Salmah Jan Noor Muhammad dan Hashim Musa, 'Pembinaan Ilmu Diplomatik Melayu dalam Menjalin Hubungan Diplomatik Antara Kerajaan', dalam Persidangan Antarabangsa Manuskrip Melayu (Kuala Lumpur: Hotel Seri Pacific, 2014), 2.

32 Jelani Harun, Pemikiran Adab Ketatanegaraan Kesultanan Melayu (Kuala Lumpur: Dewan Bahasa dan Pustaka, 2003), 275-279.

33 Adib Imran, Warkah Lama Pengungkap Peradaban Bangsa (Kuala Lumpur: Dewan Bahasa dan Pustaka, 1999), 24.

34 Rozita Che Rodi, Salmah Jan Noor Muhammad dan Hashim Musa, 'Pembinaan Ilmu Diplomatik Melayu dalam Menjalin Hubungan Diplomatik Antara Kerajaan', Persidangan Antarabangsa Manuskrip Melayu (Kuala Lumpur: Hotel Seri Pacific, 2014), 6. 
Iskandar Muda di Aceh yang menghantar warkah berhias yang paling besar dan paling cantik kepada Raja James I di England. ${ }^{35}$ Justeru, penulisan warkah harus berhati-hati dengan menggunakan bahasa yang baik, lenggok bahasa yang halus dan sopan serta reka bentuk yang indah.

Kesimpulannya, masyarakat primitif telah mengetahui dan mengaplikasikan perhubungan awam dalam kehidupan dan tadbir urus seharian mereka untuk pelbagai tujuan antaranya adalah untuk menyebarkan maklumat, membujuk, mengintegrasikan masyarakat yang pelbagai dan sebagainya.

\section{SUMBER PERHUBUNGAN AWAM ISLAM}

Perhubungan awam menurut perspektif Islam berkisar tentang jalinan dan persefahaman yang terbina antara organisasi dan masyarakat berlandaskan prinsip-prinsip yang terkandung di dalam al-Quran dan al-Sunnah serta norma masyarakat.

\section{Al-Quran}

Al-Quran merupakan sumber panduan utama bagi setiap aktiviti manusia di muka bumi ini. Dalam hal ini, al-Quran merujuk kepada kitab yang diturunkan kepada Nabi Muhammad SAW, yang tertulis di dalam mushaf, dinukilkan kepada manusia daripada Baginda SAW secara mutawatir tanpa sebarang keraguan. ${ }^{36}$ Salah satu dari pada fungsi al-Quran ialah sebagai manual atau panduan kehidupan yang terbaik kepada manusia untuk menjalani kehidupan di atas muka bumi ini. Ia sebagaimana firman Allah SWT:

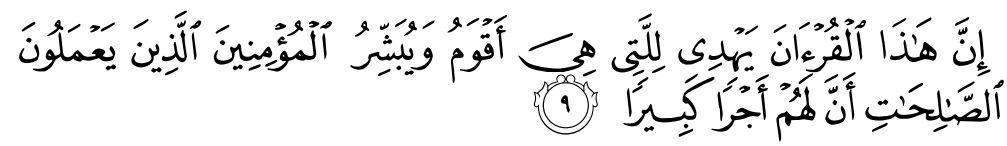

"Sesungguhnya al-Quran ini memberikan petunjuk ke jalan yang amat betul (agama Islam) dan memberikan berita yang menggembirakan orang-orang yang beriman yang mengerjakan amal-amal soleh, bahawa mereka beroleh pahala yang besar".

35 Annabel Teh Gallop, Art of the Malay Letter, ed. by E. Ulrich Katz (London: British Library Publishing, 1994), 39.

36 Aḥmad Zakī Manșūr Hammād, ‘Abu Hamid Al-Ghazali’s Juristic Doctrine,' dalam al-Muștafa min 'ilm al-Ușūl: With a Translation of Volume One of al-Muștafa min 'ilm al-Ușül' (Chicago: The University of Chicago, 1987), 59. 
(Surah al-Isrā', 17: 9)

Al-Quran juga merupakan sumber intelektual dan spiritual bagi umat Islam. Pengaruh dari pengkajian al-Quran telah meletakkan para pengkaji Islam dan ilmu mereka dalam lingkungan ketuhanan atau kerohanian. Oleh itu, pengkajian yang dijalankan dan segala bentuk pengetahuan dan penemuan baru yang ditemui itu akan mendekatkan lagi mereka dengan pencipta-Nya. ${ }^{37}$

Hakikatnya, al-Quran adalah kitab Allah SWT yang menjelaskan setiap sesuatu ilmu di dunia ini kepada manusia. Ia sebagaimana firman Allah SWT:

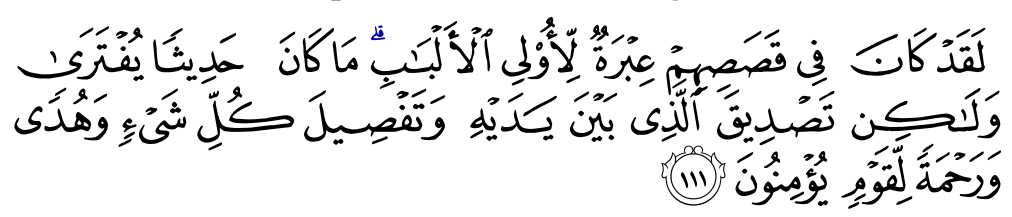

"Demi sesungguhynya, kisah Nabi-nabi itu mengandungi pelajaran yang mendatangkan iktibar bagi orang-orang yang mempunyai akal fikiran. Kisah Nabi-nabi yang terkandung dalam al-Quran bukanlah cerita yang diada-adakan, tetapi ia mengesahkan apa yang tersebut di dalam Kitab-kitab agama yang terdahulu daripadanya, dan ia sebagai keterangan menjelaskan tiap-tiap sesuatu, serta menjadi hidayah atau petunjuk dan rahmat bagi kaum yang mahu beriman."

(Surah Yūsuf, 12: 111)

Tuntasnya, al-Quran adalah sumber segala ilmu yang perlu digali dan diterokai khazanahnya sebagai panduan manusia sepanjang zaman. ${ }^{38}$ Walaupun terdapat banyak hujah yang tidak bersifat saintifik di dalam al-Quran, namun ia boleh diguna dan diterangkan secara sistematik. ${ }^{39}$

\section{Al-Sunnah}

Al-Sunnah juga merupakan sumber kedua selepas al-Quran. Dalam hal ini, Allah SWT telah meletakkan tanggungjawab yang besar kepada Nabi

\footnotetext{
37 Mohd Yusof Othman, Penghayatan Sains Melalui Al-Quran, Seminar Al-Quran, (Pulau Pinang: Jabatan Mufti Negeri Pulau Pinang, 2012), 27.

38 Kamarul Azmi Jasmi dan 'Atiqah Selamat, 'Al-Quran Satu Mukjizat Yang Menakjubkan', dalam Penciptaan Manusia dari Perspektif Al-Quran, ed. Kamarul Azmi Jasmi (Skudai: Penerbit UTM Press, 2013), 1.

39 Jawiah Dakir, 'Ulasan Buku: Sains, Masyarakat dan Agama', Jurnal Hadhari, vol. 3/1 (2011): 93-99.
} 
Muhammad SAW untuk memberi keterangan, penjelasan dan perincian yang lengkap terhadap manusia. Ia sebagaimana firman Allah SWT:

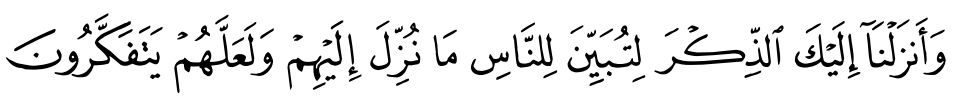

"Dan Kami turunkan kepadamu al-Quran, agar kamu menerangkan pada umat manusia apa yang telah diturunkan kepada mereka dan supaya mereka memikirkan”.

(Surah al-Naḥl, 16: 44)

Di samping itu, al-Quran dan al-Sunnah mempunyai keterikatan yang sangat signifikan. Dalam hal ini, al-Sunnah berperanan sebagai pengukuh terhadap kebenaran yang dinyatakan oleh al-Quran. Justifikasinya adalah melalui ayat yang menceritakan tentang kebersamaan antara al-Quran dan alSunnah sebagaimana firman Allah SWT:

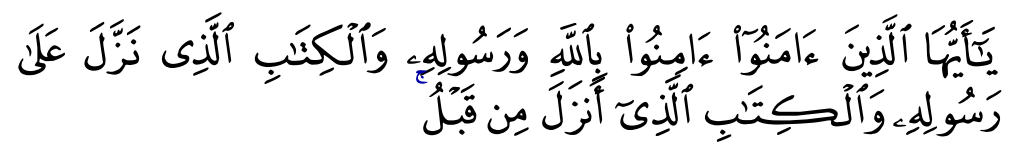

"Wahai orang-orang yang beriman, tetaplah beriman kepada Allah dan Rasul-Nya dan kepada kitab yang Allah turunkan kepada Rasul-Nya serta kitab yang Allah turunkan sebelumnya”.

(Surah al-Nisā', 4: 136)

Di dalam ayat di atas, Allah SWT memerintahkan agar manusia beriman dengan semua yang terkandung di dalam al-Quran dan juga dibawa oleh Nabi Muhammad SAW sama ada melalui perkataan, perbuatan dan perakuan. ${ }^{40}$ Al-Sunnah dalam konteks ini merujuk kepada segala sesuatu yang berasal daripada Nabi Muhammad SAW sama da berbentuk perkataan, perbuatan, persetujuan atau gambaran sifat Baginda SAW sama ada perwatakan dan pembawaan (khuluqiyyah) ataupun fizikal (khilqiyyah) dan juga riwayat hidup Baginda SAW sama ada sebelum ataupun selepas diutus menjadi Rasul. ${ }^{41}$

Menurut Yūsuf al-Qaraḍāwī, ${ }^{42}$ terdapat tiga teras utama yang menjadikan al-Sunnah sebagai panduan hidup manusia iaitu kesempurnaan, keseimbangan

40 Muḥammad Abū Zahoū, al-Muhaddith wa al-Muḥaddithūn (Bayrūt: Dār al-Kitāb al-'Arabī, 1984), 19.

41 Aminudin Basir, Mohd Radzi Othman \& Nik Yusri Musa, 'Konsep Al-Sunnah Menurut Ahli Hadith', Jurnal Pengajian Umum Asia Tenggara, vol. 8 (2006): $1-22$.

42 Yūsuf al-Qaraḍāwī, Kayfa Nat 'āmal ma' al-Sunnah al-Nabawiyyah (Riyāḍ: Maktabah al-Muayyad, 1991), 26. 
dan memudahkan. Teras kesempurnaan dalam konteks ini merujuk kepada intipati al-Sunnah yang telah mengemukakan kepelbagaian sistem atur kehidupan manusia yang teratur, terperinci dan bersesuaian dengan setiap individu tanpa membataskan kepada faktor demografi dan masa. Teras kesempurnaan dalam konteks ini pula merujuk kepada intipati al-Sunnah yang mengemukakan cara hidup yang seimbang antara keperluan rohani dan jasmani, akal dan hati, dunia dan akhirat. Teras memudahkan pula merujuk kepada intipati al-Sunnah yang mudah untuk difahami dan dilaksanakan oleh setiap individu tanpa membataskan kepada faktor demografi dan masa.

\section{Norma Masyarakat}

Islam adalah agama yang menekankan kesejahteraan dan keselesaan umatnya. Pelbagai kemudahan dikurniakan oleh Allah SWT untuk dinikmati oleh manusia bagi menjamin kelancaran hidup. Untuk itu, Islam membuka ruang yang luas bagi umatnya mengguna dan mengamalkan apa jua yang telah menjadi kebiasaan sebagai salah satu teras dalam pembentukan sesuatu hukum. Walaupun terdapat sarjana Islam yang tidak mengiktirafnya sebagai salah satu sumber yang muktabar, namun para sarjana Islam mengiktirafnya sebagai salah satu sumber yang amat penting khususnya dalam hal yang berkaitan hubungan sesama manusia.

Dalam konteks ini, norma masyarakat merujuk kepada peraturan, adat dan kebiasaan dalam sesebuah masyarakat. ${ }^{43}$ Dalam hal ini, terdapat empat fungsi norma masyarakat. ${ }^{44}$ Pertama, ia berfungsi sebagai pedoman dan aturan dalam melayari kehidupan bermasyarakat. Kedua, ia berfungsi untuk mengatur tingkah laku masyarakat sesuai dengan adat dan kebiasaan setempat. Ketiga, ia berfungsi untuk mencapai tujuan bersama. Keempat, ia berfungsi untuk memastikan keteraturan dan keseimbangan dalam lingkungan masyarakat.

Secara asasnya, norma masyarakat ini boleh diklasifikasikan kepada dua iaitu dibenarkan dan dicela. Norma masyarakat yang dibenarkan adalah kebiasaan bagi manusia yang tidak bertentangan dengan dalil yang terkandung di dalam al-Quran dan al-Sunnah. Selain itu, ia juga tidak menjurus atau membawa kepada kemudaratan. ${ }^{45}$ Norma masyarakat yang tercela atau dilarang

$43 \quad$ Kamus Dewan, $4^{\text {th }}$ ed. (Kuala Lumpur: Dewan Bahasa dan Pustaka, 2005), 2906.

44 R. Parmono, 'Nilai dan Norma Masyarakat', Jurnal Filsafat, vol. 23 (1995): 2027.

45 Șāliḥ 'Iwāḍ, al-Āthār al- 'Urf fì al-Tashrī al-Islāmī (Miṣr: Dār al-Kitāb al-Jami', 1969), 52. 
pula merujuk kepada kebiasaan bagi manusia yang bertentangan dengan Syarak atau menghalalkan sesuatu yang diharamkan atau mengharamkan sesuatu yang dihalalkan. ${ }^{46}$ Selain itu, sesuatu perkara yang boleh membawa kemudaratan serta tidak mendatangkan kebaikan juga tergolong dalam norma masyarakat yang tercela atau dilarang. ${ }^{47}$

Kesimpulannya, prinsip perhubungan awam Islam yang akan dikemukakan ini adalah dengan mengambil kira dua sumber penting dalam kehidupan manusia iaitu al-Quran dan al-Sunnah. Dalam masa yang sama perhubungan awam Islam tidak pernah meminggirkan norma masyarakat selagi ia tidak bertentangan dengan syariat Islam.

\section{METODOLOGI KAJAN}

Kajian ini merupakan kajian berbentuk kualitatif dengan menggunapakai kaedah kajian perpustakaan. Berdasarkan tajuk kajian ini, proses pengumpulan data dilakukan melalui penelitian terhadap beberapa sumber rujukan dari pelbagai bidang seperti al-Quran, al-Sunnah dan sejarah. Selain itu juga, kajian-kajian lepas yang berhubungkait dengan tajuk kajian juga turut diteliti bagi menyokong dapatan kajian.

Data yang diperoleh dari pelbagai sumber dan bidang ini akan dianalisis menggunapakai kaedah analisis kandungan ketara (manifest content) dan analisis kandungan tidak ketara (latent content). Kedua-dua kaedah ini dilihat sebagai pendekatan yang sistematik dan sesuai untuk diaplikasikan dalam kajian ini. Analisis kandungan ketara merujuk kepada penelitian secara literal terhadap kandungan sumber rujukan yang diteliti, manakala analisis kandungan tidak ketara pula merujuk kepada usaha pengkaji dalam mengemukakan suatu tafsiran terhadap kandungan sumber rujukan yang telah diteliti. ${ }^{48}$

\section{PRINSIP PERHUBUNGAN AWAM ISLAM}

Prinsip merujuk kepada sesuatu yang menjadi panduan, dasar atau pegangan sama ada dalam bentuk pemikiran, tindakan dan lain-lain. ${ }^{49}$ Tidak banyak

\footnotetext{
46 'Abd al-Wahhāb Khalāf, 'llm Ușūl al-Fiqh (Bayrūt: Dār al-Qalam, 1986), 90.

47 'Abd al-Karīm Zaydān, al-Wajīz fì Ușūl al-Fiqh (Bayrūt: Mu'asasah al-Risālah, 1987), 252.

48 Sabitha Marican, Kaedah Penyelidikan Sains Sosial (Kuala Lumpur: Pearson Malaysia, 2005), 171.

49 Kamus Dewan, $4^{\text {th }}$ ed. (Kuala Lumpur: Dewan Bahasa dan Pustaka, 2005), 3298.
} 
pengkajian atau perbahasan terdahulu yang memberi tumpuan kepada prinsip perhubungan awam Islam secara khusus. Justeru, berdasarkan penelitian yang telah dilakukan, terdapat lima prinsip perhubungan awam Islam yang seharusnya menjadi teras kepada perhubungan awam Islam di setiap organisasi khususnya organisasi yang berteraskan Islam.

\section{Membina Persefahaman}

Membina persefahaman dalam pola masyarakat yang pelbagai memerlukan usaha yang jitu dari pelbagai pihak. Dalam era modenisasi kini, semakin ramai yang bersikap individualistik kerana hanya mementingkan kesempurnaan diri dan sanggup melakukan apa sahaja demi mencapai matlamat tersebut. Justeru, sikap ini wajar dijauhi. Dalam konteks ini, membina persefahaman sewajarnya menjadi asas yang utama dalam setiap perhubungan awam sesebuah organisasi untuk mendepani kepelbagaian latar belakang, sosio-budaya, agama dan lainlain seterusnya mengelakkan permusuhan, persengketaan atau perbalahan. Prinsip ini selari dengan firman Allah SWT:

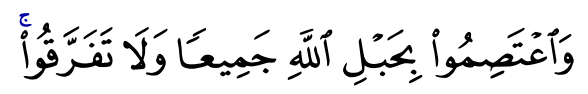

"Dan berpegang teguhlah kamu sekalian kepada tali Allah (agama Islam), dan janganlah kamu bercerai-berai”.

(Surah Āli-'Imrān, 3: 103)

Al-Qurtubi ${ }^{50}$ dalam tafsirnya menjelaskan bahawa ayat ini bermaksud larangan atau tegahan agar manusia tidak berpecah disebabkan terlalu mengikut hawa nafsu dan kehendak yang berbeza. Ahmad Hidayat et al. ${ }^{51}$ pula meringkaskan dalam penulisan mereka bahawa ayat tersebut secara jelas mengiktiraf kepelbagaian manusia dengan tujuan menggalakkan berlakunya interaksi dan bekerjasama di samping perlu mengelakkan sebarang konflik, perbalahan atau persengketaan. Dalam hal ini, perbezaan yang wujud wajar disantuni manakala persefahaman yang yang terbentuk wajar diperteguhkan. Seharusnya, budaya kesalingan wajar dipupuk untuk memastikan perbezaan yang wujud tidak mewujudkan konflik.

Antara peristiwa yang menggambarkan pengaplikasian prinsip ini dalam perjalanan hidup Nabi Muhammad SAW adalah peristiwa termeterainya

\footnotetext{
50 Al-Qurțubī, al-Jāmi ' li Ahkē̄m al-Qur'ān, ed. 'Abd al-Razāq al-Mahdī (Qahirah: Dār al-Mațābī al-Shab, 1999), 250.

51 Ahmad Hidayat Buang, Nazri Muslim dan Nik Yusri Musa, 'Hubungan Etnik di Malaysia dari Perspektif Islam’, Kajian Malaysia, vol. 29/1 (2011): 1-28.
} 
Perjanjian Hudaibiyah. Ia berlaku rentetan dari keberangkatan Nabi Muhammad SAW bersama 1400 orang Islam dari Madinah menuju ke Mekah untuk menunaikan haji. Kerajaan musyrikin Mekah ketika itu telah menghantar utusan datang menemui Baginda SAW untuk mendapatkan penjelasan berkaitan tujuan kehadiran mereka. Maka, Nabi Muhammad SAW telah mengutuskan Uthman bin Affan bagi menjelaskan kepada pembesar Quraisy secara berhikmah tujuan kehadiran mereka ke Mekah.

Walau bagaimanapun, khabar angin berlegar dalam kalangan delegasi Nabi Muhammad SAW bahawasanya utusan Baginda SAW tersebut telah dibunuh. Hal ini telah membangkitkan kemarahan dalam kalangan umat Islam. Justeru, kerajaan musyrikin Mekah telah mengutuskan utusan bagi menjelaskan situasi sebenar seterusnya membuat perjanjian dengan Nabi Muhammad SAW yang dinamakan Perjanjian Hudaibiyah. ${ }^{52}$

Masyarakat di Malaysia sememangnya terkenal dengan semangat permuafakatan dengan tujuan untuk menyempurnakan keperluan hidup sama ada bersifat kebajikan atau kepentingan umum atau peribadi. Nilainilai permuafakatan yang terbina ini akan mewujudkan kasih sayang dan mengeratkan persaudaraan dalam kalangan masyarakat. Hal ini selari dengan intipati Rukun Negara yang kelima iaitu prinsip kesopanan dan kesusilaan. Dalam hal ini prinsip kesopanan dan kesusilaan ini bertujuan bagi membentuk warganegara yang bermoral tinggi untuk mewujudkan masyarakat yang harmoni.

Dari perspektif sosiologi Islam, ia tidak pernah menafikan hak setiap manusia untuk berinteraksi dan bekerjasama selagi tidak menjurus ke arah kemaksiatan dan kemungkaran. ${ }^{53}$ Hal ini selaras dengan fitrah manusia yang tidak mampu hidup secara sendiri. Justeru, ia memerlukan kepada perkumpulan dan bekerjasama seterusnya menyumbang kepada perkembangan dimensi kemanusiaannya dalam kalangan masyarakat. Firman Allah SWT:

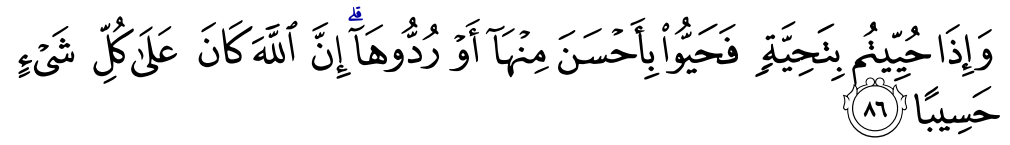

52 Muhammad Sa īid Ramaḍān al-Būṭ̣̂, Fiqh Sìrah al-Nabawiyah (Bayrūt: Dār alFikr, 1991), 405.

53 Norafifah Abdul Hamid, 'Prinsip Islam dan Nilai-Nilai Kemanusiaan', dalam Islam dan Hubungan Etnik: Sorotan Sejarah dan Isu Kontemporari di Malaysia, ed. Mohd Faizal P. Rameli (Alor Gajah: Akademi Pengajian Islam Kontemporari UiTM Melaka, 2014), 245-268. 


\begin{abstract}
"Apabila kamu diberi penghormatan dengan sesuatau penghormatan, maka balaslah penghormatan itu dengan yang lebih baik daripadanya atau balaslah penghormatan itu (dengan yang serupa). Sesungguhnya Allah SWT menghitung segala sesuatu."
\end{abstract}

(Surah al-Nisā', 3: 86)

Berdasarkan ayat di atas, dapat dirumuskan bahawa manusia adalah makhluk sosial yang memerlukan antara satu dengan yang lain. Oleh itu, menjalinkan persefahaman dalam kalangan manusia adalah dituntut bagi membentuk sebuah masyarakat yang ideal dan harmoni. ${ }^{54}$

\title{
2. Menegakkan Kebenaran
}

Dalam membicarakan tentang hakikat kebenaran, terdapat perbezaan antara setiap tingkat kebenaran yang diperolehi oleh manusia. Tingkat kebenaran tersebut diteliti melalui teori koresponderasi (the correspondence theory), teori koherensi (the coherence theory) dan teori pragmatis (the pragmatic theory). ${ }^{55}$

Teori korespondesi merujuk kepada kebenaran sebagai kesesuaian antara pernyataan tentang sesuatu dengan kenyataan itu sendiri. Teori koherensi pula merujuk kepada kebenaran sebagai keselarasan antara pernyataan dengan penyataan yang lain dan sudah diketahui, diterima dan diakui kebenarannya. Teori pragmatis pula merujuk kepada kebenaran sebagai suatu pernyataan yang bersifat fungsional dan boleh digunakan dalam praktis kehidupan.

Hal ini berbeza dengan tingkat kebenaran menurut Ibnu Sina. Menurut Ibnu Sina, tingkat kebenaran boleh dikategorikan kepada tiga. ${ }^{56}$ Pertama, filosifi (logik akal). Kedua, eksistensi (realiti). Ketiga, agama (intuitif).

Dari perspektif Islam pula, kebenaran bukan sekadar merujuk kepada pemikiran tentang hakikat kebenaran sahaja tetapi perlu dihubungkaitkan dengan realiti. ${ }^{57}$ Dalam erti kata lain, kebenaran adalah sesuatu yang berada di dalam akal dan di luar akal. Hal ini selari dengan terminologi yang dikemukan

54 Zuly Qadir, 'Mempertimbangkan Metode Integralistik: Sosiologi Untuk Kajian Islam dan Sosial', Jurnal Sosiologi Reflektif, vol. 10/2 (2016): 1-14.

55 Ahmad Atabik, 'Teori Kebenaran Perspektif Filsafat Ilmu', Fikrah, vol. 2/1 (2014): 253-271.

56 Imron Mustofa, 'Konsep Kebenaran Ibnu Sina', Kalimah: Jurnal Studi Agama dan Pemikiran Islam, vol. 15/1 (2017): 15.

57 Imron Mustofa, 'Konsep Kebenaran Ibnu Sina', 4. 
oleh Aristoteles yang turut menyatakan bahawa kebenaran adalah penyesuaian antara pemikiran dan kenyataan. ${ }^{58}$

Dalam hal ini, kebenaran boleh dikategorikan kepada dua perspektif. Pertama, perspektif konsep (nazariyyah). Ia merujuk kepada ketentuan yang saling berhubung dengan perkara-perkara yang telah diketahui namun tidak dipraktiskan. Kedua, perspektif praktis ('amaliyyah). Ia merujuk kepada ketentuan yang saling berhubung dengan perkara-perkara yang telah diketahui dan dipraktiskan. ${ }^{59}$

Justeru, kebenaran dalam konteks perhubungan awam seharusnya meliputi segala aspek pemikiran, tutur kata dan perbuatan. Dalam hal ini, Allah SWT memerintahkan umatnya agar sentiasa menegakkan kebenaran dan mengelakkan diri dari melakukan penyelewengan atau pendustaan. Ia sebagaimana firman Allah SWT:

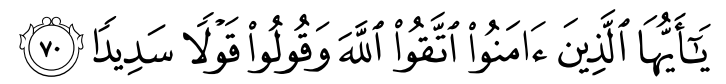

"Hai orang-orang yang beriman, bertakwalah kamu kepada Allah dan katakanlah perkataan yang benar."

(Surah al-Aḥzāb, 33: 70)

Nabi Muhammad SAW juga turut menuntut umatnya agar memperkatakan sesuatu yang benar sekalipun ianya sulit atau pahit untuk dikhabarkan. Sabda Nabi Muhammad SAW:

$$
\begin{aligned}
& \text { قُل الْحَقَّ وَإِنْ كَانَ مورَّا } \\
& \text { "Katakanlah benar sekalipun ianya pahit." } 60
\end{aligned}
$$

Dalam hal ini, Nabi Muhammad SAW telah menunjukkan teladan ketika mana Baginda SAW mengutuskan surat melalui utusannya iaitu Dihyah bin Khalifah al-Kalbi kepada Raja Heraclius iaitu pemerintah Empayar Rom ketika itu. Ketika menerima surat tersebut, Raja Heraclius telah memanggil pedagang arab yang berdagang di negaranya untuk mengetahui sama ada Nabi Muhammad SAW pernah berdusta sebelum diangkat menjadi nabi. Pedagang arab menjelaskan bahawa Baginda SAW tidak pernah berdusta walau sekalipun. Lantas Raja Heraclius telah mengutus surat balas kepada

58 Martin Heidegger, Pathmarks, ed. William McNeill (Cambridge: Cambridge University Press, 1998), 138.

59 Imron Mustofa, 'Konsep Kebenaran Ibnu Sina', 4.

60 Al-Bayhaqī, al-Jāmi 'Sha 'b al-İmān (Riyāḍ: Maktabah al-Rashād, 2003), no. hadis 4737 . 
Nabi Muhammad SAW yang menyatakan bahawa baginda telah memeluk Islam seraya menyelitkan hadiah kepada Baginda SAW. ${ }^{1}$

Dalam konteks kehidupan bermasyarakat, janji yang diungkapkan seharusnya dikotakan kerana salah satu penilaian seseorang pada seseorang yang lain adalah terletak pada janji yang telah diberikan. Hal ini seiring dengan peribahasa melayu "kerbau berpegang kepada talinya, manusia berpegang pada janjinya". Selain itu, menegakkan kebenaran merupakan salah satu kayu ukur bagi menentukan status dan kemajuan sesebuah tamadun selain turut berperanan sebagai salah satu sendi dalam memastikan kemaslahatan hubungan sesama manusia.

\section{Mengotakan Janji}

Secara umumnya, janji bermaksud hubungan atau keterikatan antara dua orang atau lebih yang dinyatakan dengan ucapan atau tulisan yang bersifat mengikat. Janji juga merujuk kepada kesediaan untuk melakukan dan memberi sesuatu manakala kata-kata pula merupakan sesuatu yang diucapkan atau dituturkan. ${ }^{62}$ Dalam hal ini, terdapat tiga elemen bagi menentukan ia menjadi satu janji. ${ }^{63}$ Pertama, terdapat dua pihak atau lebih yang melakukannya. Kedua, ikrar penjanjian. Ketiga, sesuatu yang dijanjikan.

Hakikatnya, implikasi sesuatu janji yang dilafazkan adalah sangat besar terhadap orang yang menabur janji. Dalam hal ini, Allah SWT sangat murka terhadap hambanya yang hanya pandai berkata-kata atau menabur janji tetapi tidak mengotakan apa yang dijanji dan diperkatakan tersebut. Hal ini sebagaimana firman Allah SWT:

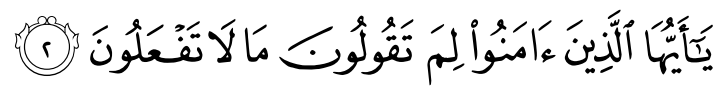

"Wahai orang-orangyang beriman, kenapakah kamumengatakan sesuatu yang tidak kamu kerjakan?”

(Surah al-Șaff, 61: 2)

\footnotetext{
${ }^{61}$ Moenawar Chalil, Kelengkapan Tarikh Nabi Muhammad II. (Jakarta: Gema Insani, 2001), 394.

62 Kamus Dewan, 4th ed. (Kuala Lumpur: Dewan Bahasa dan Pustaka, 2005), 1605.

63 Hafid Muhyiddin Baehaqi, 'Janji Antar Manusia dalam Al-Quran' (Disertasi Sarjana, Fakultas Ushuluddin dan Dakwah, Institut Agama Islam Negeri (IAIN) Ponorogo, 2020), 15.
} 
Nabi Muhammad SAW turut menjelaskan ancaman terhadap mereka yang tidak mengotakan janji atau yang telah diberikan. Sabda Baginda SAW:

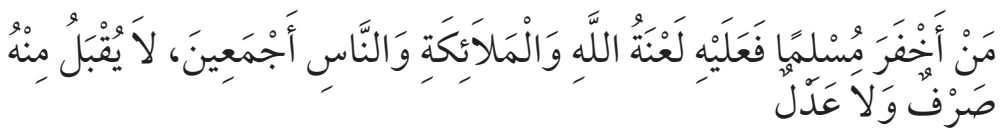

"Barangsiapa yang tidak menepati janji seorang muslim, maka dia akan mendapat laknat Allah SWT. malaikat dan seluruh manusia, tidak diterima darinya taubat dan tebusan." 64

\section{Laras Bahasa yang Baik}

Laras bahasa ialah kelainan atau variasi bahasa yang dilihat dari sudut penggunaan berdasarkan latar belakang sosial, konteks dan fungsinya. ${ }^{65}$ Oleh itu, laras bahasa sentiasa mempamerkan perbezaan dalam penggunaannya. Ini kerana, pemilihan sesuatu laras bahasa adalah bersesuai dengan bidang atau fokus yang ingin diperkatakan untuk mencapai matlamat yang diharapkan. Dalam hal ini, Islam melarang penggunaan kata-kata yang buruk dan keji dalam perhubungan awam termasuklah terhadap musuh Islam. Ia sebagaimana firman Allah SWT:

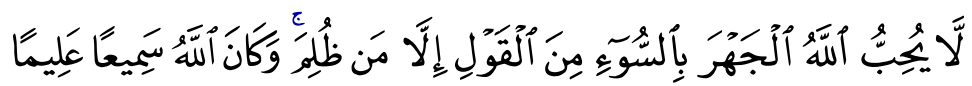

"Allah tidak menyukai ucapan buruk, (yang diucapkan) dengan terus terang kecuali oleh orang yang dianiaya. Allah adalah Maha Mendengar lagi Maha Mengetahui."

(Surah al-Nisā', 4: 148)

Antara contoh penggunaan laras bahasa yang sesuai yang diaplikasikan oleh Nabi Muhammad SAW adalah ketika berhadapan dengan dua kelompok iaitu golongan Badwi dan golongan Ansar. Baginda SAW menggunakan laras bahasa yang berbeza disebabkan perbezaan latar belakang dan sosio-budaya kedua-dua masyarakat tersebut. Walau bagaimanapun, dari aspek objektifnya

64 Al-'Asqalānī, Fatḥ al-Bārī (Jakarta: Pustaka Azzam, 2011), no. hadis 3001.

65 Abdullah Hassan, Bahasa Melayu Sebagai Bahasa Ilmu dan Esei-Esei Lain (Shah Alam: Penerbit Fajar Bakti, 1997), 248. 
adalah sama. Jika diteliti, golongan Badwi merupakan masyarakat nomad, manakala golongan Ansar merupakan penduduk tetap di Madinah. ${ }^{66}$

Masyarakat di Malaysia terkenal dengan sifat keramahannya. Justeru, sikap sombong dan menggunakan bahasa yang kasar ketika berinteraksi dengan orang lain wajar dijauhi manakala penggunaan laras bahasa yang baik dan sopan santun wajar diterap dan dilaksanakan kerana ia merupakan asas dalam menghasilkan interaksi yang harmoni dan berkesan. ${ }^{67}$

\section{Pendekatan Yang Bersesuaian}

Pendekatan perhubungan awam yang ingin dilaksanakan seharusnya bersesuaian dengan fokus khalayak sasarannya. Dalam hal ini, masyarakat boleh dikategorikan kepada tiga golongan iaitu golongan intelektual, golongan awam dan golongan antagonis. ${ }^{68}$ Oleh itu, pendekatan yang dipilih haruslah bersesuaian dengan keperluan mereka dalam usaha untuk berinteraksi dan menyampaikan maklumat kepada mereka. Hal ini selari dengan firman Allah SWT:

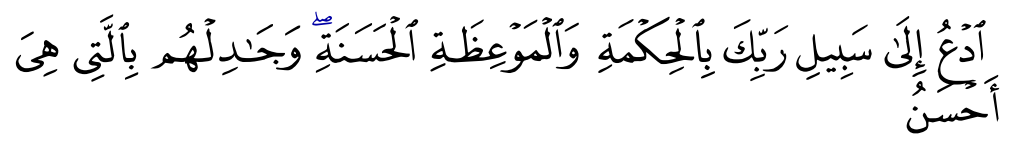

"Serulah ke jalan Tuhanmu (wahai Muhammad) dengan hikmat kebijaksanaan dan nasihat pengajaran yang baik, dan berbahaslah dengan mereka (yang engkau serukan itu) dengan cara yang lebih baik."

(Surah al-Naḥl, 16: 125)

Dalam konteks ini, pendekatan perhubungan awam Nabi Muhammad SAW boleh dibahagikan kepada beberapa kaedah antaranya mengajar, mendidik dan

66 Mohd Faizal Kamsani, Nurul Asiah Fasehah Muhamad, Rozita Abdullah, Norjihan Jaafar \& Nor Zulaili Mohd Ghazali, 'Tindak Tutur Perbualan Bersama Golongan Badwi dan Ansar: Analisa Strategi Komunikasi Rasulullah', Jurnal Komunikasi, vol. 35/3 (2019): 334-352.

67 Mohd Faizal Kamsani, Nurul Asiah Fasehah Muhamad, Rozita Abdullah, Norjihan Jaafar dan Nor Zulaili Mohd Ghazali, 'Tindak Tutur Perbualan Bersama Golongan Badwi dan Ansar: Analisa Strategi Komunikasi Rasulullah', 334-352.

68 Khairul Azhar Meerangi, Ahmad Faqih Ibrahim dan Muhammad Hilmi Mat Johar, 'Prinsip Asas Interaksi Inter-Agama Menurut Perspektif Islam', Kolokium Penyelidikan Kebangsaan (Masjid Tanah: Kolej Universiti Islam Melaka, 2018), 872-885. 
melatih. Ia bergantung kepada situasi dan khalayak sasaran Baginda SAW. Ini kerana, matlamat bagi mengubah sikap dan perilaku masyarakat bukanlah suatu yang boleh dilakukan melalui satu pendekatan semata-mata bahkan ia memerlukan pendekatan bertahap atau berlainan. Di samping itu, pendekatan perhubungan awam yang dipraktikkan oleh Nabi Muhammad SAW juga menunjukkan bahawa Baginda SAW sangat mementingkan aspek keperluan dan kemampuan untuk mencerna maklumat dalam kalangan masyarakat. ${ }^{69}$

Kesimpulannya, prinsip perhubungan awam Islam merupakan suatu nilai fundamental yang menjadi teras atau dasar kepada sesuatu keputusan dan tindakan perhubungan awam berlandaskan al-Quran dan al-Sunnah. Dalam masa yang sama, perhubungan awam Islam tidak pernah mengetepikan aspek norma kehidupan bermasyarakat seperti undang-undang, kesusilaan, kesopanan dan lain-lain. Integrasi ketiga-tiga elemen iaitu al-Quran, al-Sunnah dan norma kehidupan bermasyarakat akan membentuk satu perhubungan awam Islam yang efektif melangkaui sempadan geografi dan masa.

\section{KESIMPULAN}

Makalah ini membincangkan prinsip perhubungan awam menurut perspektif Islam melalui penelitian terhadap sejarah perhubungan awam Islam, definisi perhubungan awam Islam, sumber perhubungan awam Islam dan prinsip perhubungan awam Islam. Kesimpulan daripada penelitian yang telah dilakukan adalah seperti berikut. Pertama, dari sisi pandang sejarah, perhubungan awam bukanlah suatu istilah yang baru malah ia merupakan satu pendekatan yang telah diaplikasikan sejak zaman-berzaman. Walau bagaimanapun, transisi masa telah memberi impak terhadap perkembangan kaedah pengaplikasian perhubungan awam di dunia. Kedua, antara keunikan perhubungan awam menurut perspektif Islam adalah dari aspek konseptual khususnya dari aspek fundamental yang mendasarinya. Ketiga, sumber perhubungan awam Islam adalah berteraskan al-Quran dan al-Sunnah. Dalam masa yang sama ia tidak mengetepikan peranan norma masyarakat selagi tidak bertentangan dengan syariat Islam. Keempat, lima prinsip perhubungan awam Islam yang diketengahkan adalah integrasi ketiga-tiga sumber iaitu al-Quran, al-Sunnah dan norma masyarakat. Pengaplikasian kelima-lima prinsip Islam ke dalam perhubungan awam bakal memberi suatu kelainan dan kelebihan dari aspek matlamat yang ingin dicapai dan juga pendekatan yang dilaksanakan.

69 Halimatus Sakdiah, 'Komunikasi Interpersonal Sebagai Strategi Dakwah Rasulullah', Alhadharah Jurnal Ilmu Dakwah, vol. 15/30 (2016): 39-51. 
Sebagaimana yang telah dimaklumi bahawa perbahasan secara ilmiah berkaitan perhubungan awam Islam sebenarnya masih baru walaupun dari aspek praktisnya telah lama dilaksanakan. Justeru, ruang penelitian dan perbahasan terhadapnya adalah masih terbuka luas. Implikasi daripada penelitian ini akan membawa kepada perkembangan pengkajian dan gambaran secara teoritis dalam bidang perhubungan awam amnya dan perhubungan awam Islam khususnya. Justeru, makalah ini masih dianggap berada diperingkat awal dan memerlukan kepada kajian lanjutan khususnya berbentuk empirikal.

\section{RUJUKAN}

'Abd al-Karīm Zaydān, al-Wajīz fì Ușūl al-Fiqh (Bayrūt: Mu'asasah alRisālah, 1987).

'Abd al-Wahhāb Khalāf, 'llm Uṣūl al-Fiqh (Bayrūt: Dār al-Qalam, 1986).

Al-'Asqalānī, Fatḥ al-Bārī, (Jakarta: Pustaka 'Azzam, 2011).

Abdullah Hassan, Bahasa Melayu Sebagai Bahasa Ilmu dan Esei-Esei Lain (Shah Alam: Penerbit Fajar Bakti, 1997).

Adib Imran, Warkah Lama Pengungkap Peradaban Bangsa (Kuala Lumpur: Dewan Bahasa dan Pustaka, 1999).

Ahmad Atabik, 'Teori Kebenaran Perspektif Filsafat Ilmu', Fikrah, vol. 2/1 (2014): 253-271.

Ahmad Hidayat Buang, Nazri Muslim dan Nik Yusri Musa, 'Hubungan Etnik di Malaysia dari Perspektif Islam', Kajian Malaysia, vol. 29/1 (2011): $1-28$.

Aḥmad Zakī Manșūr Hammād, 'Abu Hamid Al-Ghazali’s Juristic Doctrine,' dalam al-Muștafa min 'ilm al-Usūl: With a Translation of Volume One of al-Muștafa min 'ilm al-Ușul' (Chicago: The University of Chicago, 1987).

Aminudin Basir, Mohd Radzi Othman \& Nik Yusri Musa, 'Konsep Al-Sunnah Menurut Ahli Hadith', Jurnal Pengajian Umum Asia Tenggara, vol. 8 (2006): 1-22.

Annabel Teh Gallop, Art of the Malay Letter, ed. E. Ulrich Katz (London: British Library Publishing, 1994).

Azneal Ishak, 'Ismail Sabri Defends Flip-Flop SOPs Following Public Outrage', Malaysiakini, https://www.malaysiakini.com/news/574302, dicapai pada 19 Mei 2021.

Al-Bayhaq̄̄̄, al-Jāmi 'Sha 'b al-Īmān (Riyāḍ: Maktabah al-Rashād, 2003). 
Al-Bukhārī, Șaḥ̄ḥ al-Bukhārī (Bayrūt: Dār Ibn Kathīr, 2002).

Dennis L. Wilcox, Glen T. Cameron dan Bryan H. Reber, Public Relations: Strategies and Tactics, $11^{\text {th }}$ edn (New York: Pearson Education Inc, 2015).

Ekhwan Haque Fazlul Haque, 'SOP Tahun Baru Cina Hasil Persetujuan dengan 21 Pertubuhan Agama Berkaitan', MyMetro, <https://www. hmetro.com.my/mutakhir/2021/02/671619/sop-tahun-baru-cina-hasilpersetujuan-dengan-21-pertubuhan-agama-berkaitan>, dicapai pada 18 Mei 2021.

Hafid Muhyiddin Baehaqi, 'Janji Antar Manusia dalam Al-Quran' (Disertasi Sarjana, Fakultas Ushuluddin dan Dakwah, Institut Agama Islam Negeri (IAIN) Ponorogo, 2020).

Halimatus Sakdiah, 'Komunikasi Interpersonal Sebagai Strategi Dakwah Rasulullah', Alhadharah Jurnal Ilmu Dakwah, vol. 15/30 (2016): 39-51.

Imron Mustofa, 'Konsep Kebenaran Ibnu Sina', Kalimah: Jurnal Studi Agama dan Pemikiran Islam, vol. 15/1 (2017): 1-18.

James E. Grunig \& Fred C. Repper, 'Strategic Management, Publics and Issues', dalam Excellence in Public Relations and Communication Management, ed. James E. Grunig (New Jersey: Lawrence Erlbaum, 1992), 109-114.

James E. Grunig dan Larissa A. Grunig, Guidelines for Formative and Evaluative Research in Public Affairs (Maryland: University of Maryland, 2001).

Jawih Dakir, 'Ulasan Buku: Sains, Masyarakat dan Agama', Jurnal Hadhari, vol. 3/1 (2011): 93-99.

Jelani Harun, Pemikiran Adab Ketatanegaraan Kesultanan Melayu (Kuala Lumpur: Dewan Bahasa dan Pustaka, 2003).

Kamarul Azmi Jasmi dan 'Atiqah Selamat, 'Al-Quran Satu Mukjizat Yang Menakjubkan', dalam Penciptaan Manusia Dari Perspektif Al-Quran, ed. Kamarul Azmi Jasmi (Skudai: Penerbit UTM Press, 2013).

Kamus Dewan, $4^{\text {th }}$ ed. (Kuala Lumpur: Dewan Bahasa dan Pustaka, 2005).

Kevin Moloney, Rethinking Public Relations: PR Propaganda and Democracy, 2nd edn (Oxfordshire: Routledge, 2006).

Khairul Azhar Meerangi, Ahmad Faqih Ibrahim dan Muhammad Hilmi Mat Johar, 'Prinsip Asas Interaksi Inter-Agama Menurut Perspektif Islam', Kolokium Penyelidikan Kebangsaan (Masjid Tanah: Kolej Universiti Islam Melaka, 2018), 872-885. 
Lothrop Stoddard, The New World of Islam (London: Chapman and Hall Ltd, 1922).

Manșūr 'Uthmā̄n Muhammad Zīn, al-Manẓūr al-Islāmī lil Ālāqāt al- 'Āmah (Omdurman, Sūdān: Omdurman Islamic University, 2008).

Martin Heidegger, Pathmarks, ed. William McNeill (Cambridge: Cambridge University Press, 1998).

Md Shahidul Haque dan Jamilah Ahmad, 'The Role of Islamic Public Relations in Leadership', International Conference on Islamic Leadership and Management (ICILM 2016) (Bandar Seri Begawan: Universiti Islam Sultan Sharif Ali, 2016), 252-264.

Michael H. Hart, The 100: A Ranking of the Most Influential Persons in History, 2nd edn (New York: Hart Publishing Company, 1992).

Moenawar Chalil, Kelengkapan Tarikh Nabi Muhammad II. (Jakarta: Gema Insani, 2001).

Mohamed Kirat, 'The Islamic Roots of Modern Public Relations and Corporate Social Responsibility', International Journal of Islamic Marketing and Branding, vol. 1/1 (2015): 97-112.

Mohd Faizal Kamsani, Nurul Asiah Fasehah Muhamad, Rozita Abdullah, Norjihan Jaafar dan Nor Zulaili Mohd Ghazali, 'Tindak Tutur Perbualan Bersama Golongan Badwi dan Ansar: Analisa Strategi Komunikasi Rasulullah', Jurnal Komunikasi, vol. 35/3 (2019): 334-352.

Mohd Yusof Othman, Penghayatan Sains Melalui Al-Quran, Seminar AlQuran, (Pulau Pinang: Jabatan Mufti Negeri Pulau Pinang, 2012).

Mokhtarrudin Ahmad, 'Amalan Perhubungan Awam: Kajian Terhadap Kecemerlangan dan Amalan Perhubungan Awam di Organisasi Tersenarai di Bursa Malaysia' (Tesis Doktor Falsafah, Pusat Pengajian Komunikasi, Universiti Sains Malaysia, Pulau Pinang, 2011).

Muḥammad Abū Zahoū, al-Muhaddith wa al-Muḥaddithūn (Bayrūt: Dār alKitāb al-'Arabī, 1984).

Muḥammad Sa '̄id Ramaḍān al-Būṭin, Fiqh Sìrah al-Nabawiyah (Bayrūt: Dār al-Fikr, 1991).

Mustafa As-Syibaie, Sirah Nabi Muhammad SAW Pengajaran dan Pedoman, terj. Bahagian Penterjemahan dan Suntingan Pustaka Salam Sdn. Bhd. (Rawang: Pustaka Salam, 2010).

Nik Roskiman Abdul Samad, 'Peranan Media dalam Melestarikan Masyarakat Kasih Sayang', Prosiding Wacana Keputeraan Sultan Muhammad V (Jeli: Universiti Malaysia Kelantan, 2015), 181-192. 
Norafifah Abdul Hamid, 'Prinsip Islam dan Nilai-Nilai Kemanusiaan,' dalam Islam dan Hubungan Etnik: Sorotan Sejarah dan Isu Kontemporari di Malaysia, ed. Mohd Faizal P. Rameli (Alor Gajah: Akademi Pengajian Islam Kontemporari UiTM Melaka, 2014), 245-268.

Periasamy Muthan, 'Peranan dan Amalan Perhubungan Awam di Malaysia: Satu Kajian Kes Terhadap Pegawai Perhubungan Awam Kerajaan’ (Disertasi Sarjana, Pusat Pengajian Komunikasi, Universiti Sains Malaysia, Pulau Pinang, 2007).

Al-Qurțub̄̄, al-Jāmi ' li Ahkām al-Qur'ān, ed. 'Abd al-Razāq al-Mahdī (Miṣr: Dār al-Mațābī al-Shab, 1999).

R. Parmono, 'Nilai dan Norma Masyarakat', Jurnal Filsafat, vol. 23 (1995): 20-27.

Rex. F. Harlow, 'Public relations definitions throught the years', Public Relations Review, vol. 3/1 (1977): 49-63.

Rozita Che Rodi, Salmah Jan Noor Muhammad dan Hashim Musa, 'Pembinaan Ilmu Diplomatik Melayu dalam Menjalin Hubungan Diplomatik Antara Kerajaan', Persidangan Antarabangsa Manuskrip Melayu (Kuala Lumpur: Hotel Seri Pacific, 2014).

Sabitha Marican, Kaedah Penyelidikan Sains Sosial (Kuala Lumpur: Pearson Malaysia, 2005).

Saidathul Nizah Mat Tazin \& Kiranjit Kaur, 'Strategic Crisis Communication and Stakeholder Reactions in a Malaysian Government-Linked Company', Media Asia, vol. 41/1 (2014): 25-30.

Ṣālih 'Iwāḍ, al-Āthār al- 'Urf fì al-Tashrī' al-Islāmī (Miṣr: Dār al-Kitāb alJami’, 1969).

Scott M. Cutlip dan Glen M. Broom, Effective Public Relations (New Jersey: Prentice Hall, 2009).

Stephen P. Robbins, Organization Behavior: Concepts, Controvercies and Application, $8^{\text {th }}$ ed. (New Jersey: Prentice Hall, 1998).

Sulvinajayanti, 'Praktik Public Relation dalam Pandangan Islam', KOMUNIDA: Media Kamunikasi dan Dakwah, vol. 8/2 (2018): 134154.

Syed Arabi Idid Syed Abdullah dan Mohd Safar Hasim, Perhubungan Awam di Malaysia: Satu Kajian Tentang Pengamal di Malaysia (Bangi: Universiti Kebangsaan Malaysia, 1995). 
Tim P. Vos, 'Explaining the Origins of Public Relations: Logics of Historical Explanation', Journal of Public Relations Research, vol. 23/2 (2011): 119-140.

'Warganet Kecewa Keputusan "Flip Flop" Kerajaan Berkait PKP', Freemalaysiatoday, https://www.freemalaysiatoday.com/category/ bahasa/tempatan/2021/05/11/warganet-kecewa-keputusan-flip-flopkerajaan-berkait-pkp/>, dicapai pada 18 Mei 2021.

Yūsuf al-Qaraḍāwī, Kayfa Nat 'āmal ma al-Sunnah al-Nabawiyyah (Riyāḍ: Maktabah al-Muayyad, 1991).

Zuly Qadir, 'Mempertimbangkan Metode Integralistik: Sosiologi Untuk Kajian Islam dan Sosial,' Jurnal Sosiologi Reflektif, vol. 10/2 (2016): $1-14$. 